\title{
Towards a conceptual framework for diaspora tourism
}

\author{
Tingting Elle $\mathrm{Li}^{*}$ \\ Department of Marketing, Branding and Tourism \\ School of Business, Middlesex University London, UK \\ Elle.ting@connect.polyu.hk \\ Tel.: $+44(0) 7960520359$
}

Bob McKercher

School of Hotel and Tourism Management, The Hong Kong Polytechnic University, Hum Hong, Kowloon, Hong Kong, China

bob.mckercher@polyu.edu.hk

Eric Tak Hin Chan

Transport Studies Unit, School of Geography and the Environment, University of Oxford, Oxford, $U K$

eric-th.chan@ouce.ox.ac.uk

${ }^{*}$ Corresponding author 


\begin{abstract}
Tourism scholars and practitioners tend to treat diaspora tourism as a homogeneous market whose needs can be met by generalised types of products. This assumption results in a gap between the origin and destination dimensions of this phenomenon, which may lead to unsatisfactory visiting experiences. In this paper, we conducted a critical review on a wide range of research undertaken on diaspora, migration and home return tourism, and proposed a conceptual framework by synthesising significant themes in both dimensions identified from the review. The conceptual framework provides a holistic view for researchers and destination managers to examine diaspora tourism. It suggests that the demand dimension of diaspora tourism concerns the structure of diaspora communities; the diasporic individual's migration histories, acculturation level and sense of place will determine their motives to return; the destination dimension involves debates on the issues of why current diasporic destinations and their products may not be able to meet the needs of different types of tourists. We aim to provide a comprehensive analysis on what diasporic destinations could consider in order to satisfy the needs of diaspora tourists in their future planning and strategy development.
\end{abstract}

Keywords: diaspora tourism; migrants; critical review; sense of place; acculturation; conceptual framework

\title{
1. Introduction
}

Having been extensively used to indicate the tourism produced, consumed and experienced by diasporic communities (Coles \& Timothy, 2004), the phenomenon of diaspora tourism has gained growing interest in its various forms, leading destination managers to begin developing products to cater for this market (Maddern, 2004; Basu, 2004; 2007; Coles, 2004). It is reported that the total number of international migrants has grown by $41 \%$ since 2000 to 244 million (United Nations, 2016), and a significant number of migrants are attracted to visiting their home countries. Nonetheless, studies suggest that the ability of diasporic destinations to capitalise on market opportunities have not been fully met (Stephenson, 2002; Iarmolenko, 2015). This has resulted in unsatisfying visit experiences and limited repeat visitation (Olsen, 2006). Part of the reason may be both destination managers and researchers tend to treat diaspora as a homogeneous community whose needs can be met by generalised types of products (Collins-Kreiner \& Olsen, 2004; Coles, 2004). This assumption, though, 
has been challenged by more authors recently, pointing out that diasporic communities are heterogeneous with clearly defined subgroups that have unique and unfolding identities, demands and behaviours (Bryce, Murdy, \& Alexander, 2017; Li \& McKercher, 2016a; Weaver, Kwek, \& Wang, 2017). By using single ethnic group as a case study, this body of research provides insightful understanding to the studied diaspora's subgroups and the rationale behind their home return travel. However, despite the long and diversified histories of different diaspora groups and their sub-communities, new migration trends and growing interest in research, there is as yet no single study devoted to a comprehensive review and conceptual framework on the topic. The lack of deeper conceptual understanding and crosscultural studies represents a significant gap in diaspora tourism literature.

To fill this gap, it is timely to invite dialogues from different disciplinary domains (Weick, 1999), and explore more deeply the themes and factors that affect diaspora tourists' purposes and how the market is performing to meet these needs. A critical review will be a more effective approach to fulfil this purpose, given that studies of diasporic travel have scattered in different sources and disciplines and under so many topics. Researching on the literatures across various disciplines facilitates the researchers to go beyond simply describing the identified articles; enables them to extract significant themes and factors from the previous body of work, critically evaluate its relevance and value to the studied phenomenon, and identify conceptual contribution to embody existing theories. As such, new interpretations can be proposed through the process of evaluation, evolution and/or accretion (Grant \& Booth, 2009).

In so doing, a conceptual framework (Figure 1) is proposed to bridge the linkages across different strands of literatures and incorporate significant themes for understanding diaspora tourism from a holistic manner. In-depth insights can be obtained from the discussions on how a variety of demand-side factors influence interest in this activity, and in turn can inform destinations how they can best shape their products; and conversely, how a series of supplyside considerations influence the type of tourist that most likely to visit. The remaining parts of this article will include two main sections of detailed discussions on the origin (demand) and destination (supply) dimensions and how important themes were identified to play significant parts in diaspora tourism. They will be followed by an interpretation of the framework, conclusion remarks and future research avenues. 


\section{Understanding diasporic communities: The origin of return}

Diaspora is conceptualised as a "deterritorialised" and "transnational" population dispersing from an original homeland, who develop a strong ethnic group consciousness, alienation or a feeling of solidarity, and varied levels of desire to return home (Vertovec, 2004; Cohen, 1997; Safran, 1991). Superficially, each migrant community consists of the same or similar ethnic groups that live outside of their homelands. In reality, though, they are comprised of a variety of sub-groups, defined by reasons to migrate, time and waves of migration, the place they migrated from, how they identify themselves and whether they feel connected or disconnected to their ancestral home.

\subsection{Migration history}

\subsubsection{Reasons to migrate}

The literature of migration suggests that the reasons to migrate can be portrayed along a lifestyle to economic rational continuum, with most decisions including a mix of both (Boyne, Carswell, \& Hall, 2002). The diaspora literature further suggests that the movements may be made voluntarily or may be forced on individuals (Safran, 1991). Those who move voluntarily are labelled as "proactive" migrants (Boyne et al., 2002), and are motivated to move for a better quality of life for them or their children (Benson \& O'Reilly, 2009). While these individuals tend to maintain close ties to their homeland, they also seem to be more willing to develop strong attachments to their new place of residence, often resulting in a sense of multiple attachments to both their originating and receiving countries (Gustafson, 2001; McHugh \& Mings, 1996). They have the freedom of choice to make home return trips at their discretion to maintain their social and emotional ties. Interestingly, though, the more they assimilate with their new country, the less strong desire they may have to return home (Stedman, 2006).

"Reactive" migrants represent a group of people who are compelled to move for reasons beyond their control, such as war, famine, and political oppression (Richmond, 2002; Fussell, 2012). Here, the migration decision is often imposed, either overtly if they were expelled from their homeland or covertly if they were forced to leave to escape from intolerable situations (Ioannides \& Ioannides, 2006). Forced relocation results in a permanent break of 
physical and familial ties to home. Many of these individuals have difficulty assimilating with new places, and instead, long for their place of origin (Castles, 2000; Sampson \& Gifford, 2010). As a result, their desire to return may never vanish (King \& Christou, 2010), yet until the political situation changes, they are unable to return. Over time, and across generations, the longing for and impression of their ancestral homeland can attain something akin to a mythic place defined as much by romantic feelings as by reality. The motivations for and nature of their travel thus takes on different symbolic meanings when they or their offspring can return (Maliepaard, Lubbers, \& Gijsberts, 2010; Rumbaut, 2004).

\subsubsection{Differences across generation}

Diasporic communities are shaped by their varying migration histories in particular the time when they or their ancestors migrated (Berg, 2011; Rumbaut, 2004). Newly formed communities comprise predominantly of recent migrants, while communities with long and uninterrupted migration histories may be comprised of a mix of people who have resided in the receiving country for many generations (sometimes hundreds of years), as well as newer migrants (Eckstein, 2002). Others still have disrupted migration histories, with remnant populations existing in isolation after the introduction of racist legislation to stop others from entering. This situation is most applicable to Chinese migrants in many western countries, as a consequence of the introduction of such legislation as the American Chinese Exclusion Act in 1882, followed by similar legislation introduced in Canada, Australia and New Zealand (Kemp \& Chang, 2004). The result was an effective cessation of migration until well after the Second World War (Lee, 2003), leaving remnant Chinese populations in Chinatowns that developed over many generations.

These differences shape and reshape the social and demographic composition of diaspora communities, their identity and importantly, the members' sense of attachment to home and interest in visiting their ancestral homelands (Zhou, 2015). First-generation migrants have the most varied degrees of home identity and attachment. Some studies suggest that most of these individuals assimilate more fully into the receiving culture if they left ancestral home at a very young age (Harker, 2001; Zhou, 2015). Alternately, those who spent their formative years in ancestral home developed strong home identities and attachments and may feel a stronger responsibility to maintain ancestral traditions and practices of home culture (Drozdzewski, 2007). 
Conversely, the sense of attachment to one's homeland tends to diminish across successive generations (Maliepaard et al., 2010), for descendants of migrants become more fully assimilated with the host society, adopting host cultural norms, speaking the hosts' language and often losing their ancestors' language (Alba \& Nee, 1997). Travel patterns also change over time. Klemm (2002) found that first-generation Indian and Pakistani residents of England had a strong desire to return home, while latter generations saw it more as an obligatory duty visit rather than something to look forward to. Li and McKercher (2016a) investigated the home travel by the Chinese diaspora and identified two different types of travel patterns among descendants of earlier migrants to Canada and the USA. On the one hand, those who had largely lost their ties to China went on a journey in search of their family roots and cultural identity. On the other hand, some ethnic Chinese felt no strong ties to China and instead saw it as an interesting place to visit. They behaved much more like other tourists who happened to be ethnically Chinese rather than individuals seeking to affirm or re-affirm their identities.

\subsubsection{Difference by place and specificity of origin}

The classic notion of diaspora refers to a distinct ethnic community in a host society who originated from the same geographical area along with a shared collective identity (Safran, 1991; Brubaker, 2005). This assumption is rarely true today, and instead, migrant population often consists of communities from different regions of the homeland with notably and internally different cultural characteristics. For example, Tsai, Ying \& Lee (2000) comment on how the application of the undifferentiated label of 'Chinese' does not do justice to the innate heterogeneity of this population which consists of Chinese from multiple nationalities, such as Singapore, Indonesia, Malaysia, plus greater China of Hong Kong and Macau, as well as the multiple cultures and diverse religious groups found within greater China. Likewise, Schoene-Harwood (1998) comments on the existence of multiple 'Scotlands' defined by clan linkages and a highland/lowland split.

Most migrants have established a specific place and community identity with respect to their dwelling, community and region in ancestral home long before their migration (Cuba \& Hummon, 1993). Such sense of place would stay, sometimes longer after migrants' settlement and would play a role in the re-establishment of their place identity and new communities. Diaspora members would reunite with the ones who originated from the same specificity of origin and foster new communities in the host country based on their original 
geographical area or dialect region, such as a village, hometown, and region (Zhou \& Lee, 2015).

Diasporic travel will be affected by the extended ties built with different geographical scales of ancestral home, original place identity and re-established personal identity, and sometimes the promotion from diasporic associations (Lew \& Wong, 2004). Generally, individuals would travel towards the exact place which they identify themselves most with, such as their birth place or ancestral village of the family, depending on how close they feel with these places. Community members may expand their travel environ after attending their associations' promotion activities (Zhou \& Lee, 2015), for instance, Chinese immigrants who originated from hometown Jiangmen also conduct trips to other cities in Wuyi region, sometimes arranged by their associations.

\subsection{Level of acculturation}

Indeed, a diaspora contains a composite of subcultures, in which migrants' identities are under re-definition and transformation over the years (Tie, Holden, \& Park, 2015). As one of the main establishers in acculturation psychology, Professor John W. Berry has brought forward the long-term psychological process of acculturation in his multiple writings as being dependent on social and personal variables that reside in the society of origin, the diaspora group, the society of settlement, and the course of acculturation (Berry, 1997; Sam \& Berry, 2010). Diasporic communities must negotiate two cultures after landing in the new country. How they negotiate will be a result of complex interactions between their own personal experience, host and home attitudes they have received in years (Kim \& Oh, 2011; Schwarts, Unger, Zamboanga, \& Szapocznik, 2010). Some may acculturate well and feel like a foreigner in their own homeland (Reed-Danahay, 2015). While the others may never fully assimilate. For instance, the diaspora community's ethnic or religious clustering is imposed by the receiving country. Historical and modern situation and attitudes of the society of settlement, such as whether the government and its citizens accept, respect, or hold prejudice and discrimination against the migrant groups will affect the community's acculturation process. Also, whether the host and home communities provide social support for the migrants' settlement, employment and well-being will also play an important role. Some societies of settlement provide a positive settlement context through less enforcement of cultural change and more social support for immigrants. While others seek to eliminate 
diversity by marginalising diverse population through policies and governmental propaganda. Migrants in this context are more likely to experience a sense of alienation and isolation when they have not been fully accepted by the host society (Phinney, Horenczyk \& Liebkind, 2001). Coming together would be stress, anxiety, and frustration from living in the new society, directly affecting their acculturation level. These processes were interpreted by Ang (2014) through a discussion of probing tensions between "ethnic" identity and "national" identity, in terms of assimilation (the "ethnic" is absorbed by the "national"), multiculturalism (the "ethnic" coexists with the "national"), and the diaspora (the "ethnic" transcends the "national").

Multiculturalism suggests the possibility that a diaspora community knows and understands both home and host cultures and immigrants can alter their behaviour to fit in a particular social context for their own development (Modood, 2013; Benet-Martínez \& Haritatos, 2005; LaFromboise, Coleman, \& Gerton, 1993). Multicultural migrants can maintain a positive identity as a member of original home culture while simultaneously engaging in complex interaction with other cultural groups. In this case, ethnic and national identities do not need to fuse to solve possible internal conflicts but can coexist for a better good. Individuals can have strong flexibility and adaptability to take advantages of each culture.

Over time, though, many communities do integrate. Distant generations are more likely to adapt to the dominant culture and become socially accepted by members of this culture possibly by losing their own original cultural identity, or by adopting a hyphenated identity (Ali \& Holden, 2006). This process is referred to as cultural assimilation and structural assimilation (Gordon, 1964). An outcome of similar to integration will be likely to occur, when a high degree of structural assimilation through contact and participation in the host society is present with a low degree cultural maintenance. Many authors referred to diasporic identity when ethnic identity transcends national identity during the process of cognition, negotiation and transformation of personal and group identities (Davidson, 2008; Hollinshead, 2004).

Overall, the level of migrants' acculturation can be very difficult to measure and ethnic and national identities of migrants are in constant evolution and mutual entanglement (Ang, 2014). Diasporas as "hybrid" living "in-between cultures" in the "third space" (Bhabha, 1994), are in a process of constant negotiation, re-negotiation and de-negotiation of cultural, national and diasporic identities (Moore-Gilbert, 1997; Ali \& Holden, 2006). Clearly, the degree of 
acculturation is influenced by the number of generations that have resided in a country (Hughes \& Allen, 2010), the level of acceptance or segregation imposed on migration communities (Phinney, Horenczyk, Liebkind, \& Liebkind, 2001), whether they preferred to or were compelled to live in bounded spaces that ensured maintenance of common bonds of ethnicity, culture, religion, national identity and race (Cohen, 1997; Vertovec, 2001; Ioannides \& Ioannides, 2006), and the degree of internalised pressure to maintain traditional lifestyles, traditions and culture (Pan, 1998; Phinney et al., 2001).

Nonetheless, the members who stick to their home identity and culture have the strongest desire to conduct diasporic travel with the purpose of seeking cultural foothold and maintaining a sense of belonging which is missing in the host society (Hollinshead, 2004; Wilson \& Dissanayake, 1996). On the other hand, the more someone identifies with the host culture, the more likely their travel patterns are to reflect those of the dominant population and not of the ethnic sub-group (Feng \& Page, 2000). Thus, multicultural migrants present less strong desire to travel home because of their strong adaptability to both cultures and less urgency of returning. Their travel may occur when they have obligations to return or need to seek advantages from both cultures. The urgency and desire of travel of distant generations who integrate to the host society diminish over time. Nonetheless, some members in this group conduct seeking-oriented trips with the purpose of tracking their genealogy and reconnecting with their ancestral home (Van den Berghe, 1994).

\subsection{Variations in sense of place}

Level of acculturation is also interrelated to sense of place and place attachment that experienced by the diasporas (Mazumdar \& Mazumdar, 2009). Both are dynamic concepts influenced by such antecedent factors as the individual's perception of his or her cultural identity prior to the return trip, motives to return, resultant experiences and how strong they feel their personal, group and spiritual ties are to their ancestral place ( $\mathrm{Li} \&$ Chan, 2018). How migrants perceive the meanings of their place exists along a continuum (Stedman, 2006). Sometimes, people-place connection is quite personal, depending on one's own experience, personal milestones and memories. At other times, it can be experienced at a group or collective level (Low \& Altman, 1992), where group experiences and memories determine attachment. Some migrants develop close ties to their migration country, while others retain a stronger link to their ancestral home. More individuals develop bonds to both places where 
they have equivalently important experiences there (McHugh \& Mings, 1996; Gustafson, 2001). There are also some members who feel rootless, lacking sense of belonging or community and grieving for a lost home (McHugh \& Mings, 1996; Relph, 1976; Fried, 1963). Moreover, the degree of attachment to such places can vary from the superficial to the deep depending on the length of residence, strength of social ties, and level of mobility (Hay, 1998; Gustafson, 2001; Lewicka, 2011). Diasporas construct their sense of place in relation to the "outside" world, by integrating the local and the global, sense of self and the others, and doing so, places are continually produced and reproduced within a time-space compression (Harvey, 1993).

A number of studies suggest that individuals who maintain strong physical and social attachments to a home place conduct frequent trips to maintain such attachment (Lew \& Wong, 2004; Eng \& Davidson, 2007), while those who maintain a generic sense of home more likely to travel to the sites that represent diasporic history, heritage, beliefs, and values (Bruner, 1996). In some instances, the notion of ancestral home becomes extremely blurred especially if the members have lost track to the precise location of place of origin due to long dispersion, remigration or forced relocation prior to written histories documenting their homeland (Basu, 2007; Pinho, 2008). These individuals would travel to localities where their ancestors may have lived or to places that reflect significant historical events and take the form of a pilgrimage or spiritual journey (Timothy \& Olsen, 2006; Kelner, 2010). Li and McKercher (2016b) also observed how different senses of attachment influenced the spatial movements of tourists. Those who maintained strong private and individual affective attachment limited their movements to a small region associated with their home community, while individuals with more generic group or ethnic ties were more likely to travel widely through the home place.

\subsection{Summary of the origin dimension}

Three key dimensions that influence demand for diaspora tourism emerge from this above discussion. Reasons to migrate, generational and time differences, and differences in specificity of origin define the degree of homogeneity or heterogeneity of diasporic communities. The communities that are largely internally consistent will display generally common diasporic travel patterns, while the more diverse the community is, the more diverse its travel patterns will be. Likewise, the level of acculturation and how one defines him or 
herself as being part of an ethnic or national group will influence both the degree of urgency and patterns of spatial movements. In the meantime, sense of place and place attachment may also influence travel desire and experience. Individually, each of these three dimensions exists along a continuum and collectively they are highly interrelated. As a result, the differing mixes of these elements will influence both interest in and type of travel undertaken.

\section{Destination considerations}

Diversification of diaspora groups and their sub-communities calls for more attention from researchers, the destination management organisations (DMOs) and other stakeholders involved to understanding their ever-changing needs. More recent studies have reported attempts to segment the market by formulating various classifications and labels for diaspora tourists. Li \& McKercher (2016a), for example, identified five types of diaspora tourists, "reaffirmative", "quest", "reconnected", "distanced", and "detached", through a case of Chinese home return travellers from North America. In a similar fashion, Murdy, Alexander, and Bryce (2018) discussed tourists with "full heritage immersion", "the ancestral enthusiast", "general interest", and "heritage focused" through a detailed analysis of clusters from 282 ancestral tourists to four countries. Likewise, Weaver, Kwek, and Wang (2017) identified "Shallow", "Extrinsic", "Hybrid" and "Intrinsic" diaspora tourists through a qualitative inquiry into the experience of overseas Chinese package tour in China. Such desire of developing tourist typologies has shown increasing popularity of this activity and provided analytical and explanatory types for practitioners to understand the market. Unfortunately, the review of the supply dimension reveals that the heterogeneity of diasporas, their unfolding identities, varied demands and behaviours have not been fully understood by the stakeholders. The marketing and management methods applied by these destinations may not be well adjusted to satisfy the needs of different types of consumers. We summarise this section by discussing what are significantly related to destinations' ability to satisfy the needs of diaspora tourists.

\subsection{Roles of different stakeholders}

To understanding whether and how tourism destinations can satisfy unfolding needs of diaspora tourists, we first discuss respective roles of multiple stakeholders involved in 
diaspora tourism. In some instances, the DMOs take the lead in developing product and promoting diasporic travel. For example, the Bahamas government organises and promotes a wide array of homecoming festivals, such as Stuart Manor Homecoming Festival and Rolle Town Homecoming Festival (Bahamas Ministry of Tourism, 2017), while the Philippines Department of Tourism has also developed a number of initiatives to attract expatriate Filipinos to return home (Philippine Department of Tourism, 2017). In other instances, the DMOs see their role as more of a facilitator and marketer by adopting different distribution channels to access these tourists (Klemm, 2002; Coles, 2004). Here, e-marketing, word-ofmouth (WOM) and promotional campaigns through migrant associations have proven to be effective ways to reach diaspora groups (Morgan, Pritchard, \& Pride, 2002). Perhaps one of the most successful cases was VisitScotland's Homecoming campaign which ran in 2009 (VisitScotland, 2009). This $£ 2$ million investment campaign generated 25 million visits to its dedicated Homecoming website and over 4000 pieces of coverage worldwide with 1.1 billion audiences, through hosting over 400 press trips and 60 press events.

Other stakeholders such as private sectors and a range of non-governmental associations in both sending and receiving countries play respective roles in producing the experiences and encounters of diaspora travel (Butler, 2001; Klemm, 2002). The role of the private sector is more transparent. Local and international tour operators develop themed packages to cater to this market. Motives and themes of package tours are particularly stressed when the private sector attempts to induce as more tourist consumption as possible. Root-seeking package tour as a dominant form of such products, is arranged by local and international agencies with assistance from immigration associations and private business owners (Morgan et al., 2002; Maruyama \& Stronza, 2011; Wessendorf, 2007), or in other times sponsored by DMO to attract young adults with diaspora background to participate (Kelner, 2010). The retailers may manipulate and transform authentic experiences to diversify their tours by combining heritage attractions with other tourist activities, such as exotic or adventure tours, and neglect the genuine purposes of the market (Collins-Kreiner \& Olsen, 2004).

Non-governmental associations (also known as voluntary associations) in both sending and receiving countries play a significant role in uniting community members and promoting their return. For instance, three types of Chinese associations in both China and host countries were noticed to have catered to immigrants' needs and promoted diaspora's travel: clan and lineage; geographical, place, and dialect; and special interests' associations (Lew \& Wong, 2004; Zhou \& Lee, 2013). Some of these associations arrange home-coming tours for their 
members to keep them connected to their roots. Some others provide assistance to locate ancestral roots and disconnected family members by organising roots-seeking tours and a range of other home related activities (Lew \& Wong, 2004).

Unfortunately, although more DMOs are recognising the potential of their diaspora market, limited campaigns with differentiated strategies that target at segmented tourists have been developed (Che, 2004; Hannam, 2004). It may be a result of the differing roles of these actors and the chance of conflicts it may occur between them, and how these actors interact with each other in maintaining heritage resources, interpreting cultural meanings and values, passing on these meanings to visitors become a great challenge. Successful cooperation and communication among these actors are needed and together they will help to deliver the product which can truly connect the tourists to the place and provide something really special to one's travel experience. Oppositely, minimal communication with each other despite local, regional or national levels may increase difficulties in interpreting the meanings of heritage, predicting and solving conflicts, and deliver authentic and satisfied experience to the audiences.

\subsection{Diasporic attractions and products}

Many countries and regions have recognised the potential of diaspora tourism as a significant market niche, and many sites associated with diasporic histories are transformed into products that can be consumed by both diaspora and mass tourists. Both tangible asset that represents artefacts and reminders (e.g. museums, townscapes and fabric) and intangible manifestation with symbolic meanings and spiritual embodiments play vital parts during commodification of these destinations (Yankholmes \& McKercher, 2015; Coles, 2004; Maddern, 2004). Amongst, some destinations known for their dispersion histories and tragic incidents that have occurred in home and host countries target themselves as dark tourism sites. These sites provide experiences associated with death and suffering from representations of special meanings for dispossessed and reactive diasporic communities (Cohen, 2011; Light, 2017). Examples include many slave trading sites in Ghana, holocaust sites and memorials, and immigration stations like Angel Island on the west coast of the United States where many Asian migrants spent years before being allowed to enter the country (Mowatt \& Chancellor, 2011; Li, 2015; Cohen, 2011). 
Other types of popular diasporic attractions are pilgrimage and religious sites which reflect ethnic origins, histories, collective memories, and identities of a diasporic group (Handley, Haviser, \& MacDonald, 2006; Dann \& Seaton, 2001; Stone, 2006; Stone \& Sharpley, 2008). Some of these sites function as "intentional monuments" and they help to recall the grand narratives of the group's history. A well-known attraction is the Temple Mount which remains the holiest site in Judaism and represents the dominant image of the place where Jews turn towards during prayer. In other instances, familial sites and spaces function as "unintentional monuments" which figure in the more intimate narratives of family history, such as the graves of forebears and unknown relatives, the ruins of deserted croft houses and other settlements (Basu, 2005).

The range of diaspora tourism products is as diverse as the needs of the market and the meanings people attached to them. However, root-seeking and heritage package tour are the dominant forms of such products, arranged or sponsored by local or state agencies, immigration associations and private business owners (Morgan et al., 2002; Maruyama \& Stronza, 2011; Wessendorf, 2007; Kelner, 2010). Most of the products are developed to attract both diaspora and mass tourists, and only few destinations have developed differentiated market strategies or products to satisfy differentiated needs of tourists in different segments. For example, Collins-Kreiner \& Olsen (2004) reviewed tourism websites that oriented towards the Jewish diaspora market and noted nine types of diasporic tours, from heritage and pilgrimage tours to Jewish singles tours and youth educational tours. In most instances, diasporic destinations are running themed festivals and events to attract both former residents and their descendants and ordinary tourists to visit the place. The St. Lucia Jazz Festival in Jamaica (Nurse, 2002), Croatian film festival in New Zealand (Žabčić, 2010) are notable examples of such successful events.

\subsection{Key themes and issues in managing diasporic destinations}

\subsubsection{Manage the image of the place}

Compared to an established body of research that looks into the motives and experiences of diaspora tourists, studies on investigating the management issues of diaspora tourism sites are not adequate. Back to the question of how diasporic destinations satisfy the needs of their potential market segments, one of the greatest challenges facing by these destinations is how they understand their consumers and how the place image is built and sustained to attract the 
market. Increasing destinations adopt diaspora tourism as a core part of their positioning strategy and attempt to develop a positive image of ancestral home for migrants and their descendants. For instance, the Israeli government builds a successful home image for the Jewish diaspora through the messages of "Israel is calling and it is time to answer" and "Israel: No one belongs here more than you" within a range of homecoming programs of "Livnot u'lehibanot", “movement of Young Judea", etc. (Collins-Kreiner, 2010; Kelner et al., 2000; Shapiro, 2001). Ghana has long been associated as the centre of the Transatlantic Slave Trade, although interestingly, it downplays this association in its tourism websites and instead encourages "roots" tourism. This omission has created a gap for Sierra Leone to position itself as a slave tourism centre (BBC, 2012).

Nonetheless, the place image of diasporic destinations can be relativistic and dynamic. It is highly subjective and individuals may perceive a place differently depending on his own background and identity (Shani \& Wang, 2011). Thus, the image of a diasporic destination is greatly influenced by a range of factors, including the region's narratives of its migration history, how well established its diasporic communities are, destination's promotion strategy, and so forth. Moreover, image building is an ever-lasting process during which diasporic destinations need to explore the critical factors that influence their image building and adjust their strategies from time to time by considering different social, political and cultural factors (Shani \& Wang, 2011; Elliot, Papadopoulos \& Kim, 2011).

\subsubsection{Managing diasporic sites}

Current publications on managing diasporic sites represent that this body of literature is eclectic in its focus and themes; some topics (e.g. site management) have received considerable attention while others have not. Limited attempts have been made to propose guidelines or frameworks for managing diasporic sites (Light, 2017; Iarmolenko, 2015). It appears that academic researchers and practitioners did not have much chance to communicate with each other and the distance between them has resulted in limited exchanges of knowledge and applications of recent research findings.

Early studies suggested that the marketing and sites management of diasporic destinations were facing severe situation due to diminishing national tourism budgets, rising media costs, fading of return desire, and growing conflicts between different stakeholders (Olsen, 2006; Morgan et al., 2002). One of the challenges lie with the significant role that family has played 
in the marketing and promotion of those destinations. Diaspora tourists tend to value their family and friends' experience and advice, and some may not heavily rely on travel intermediaries as other types of tourists. Amongst, the rising role of social media in connecting diasporas, their families and the destinations becomes a new relevant topic. Many destinations begin to carry out their marketing campaigns and promote their image across multiple media platforms (Newland \& Taylor, 2010), which reflects the rising importance of information technology to management of diaspora destinations. For instance, Jordan sponsored a social media campaign run by travel bloggers who have visited Jordan to promote its local image, and the uses and gratifications in social media were proved to be effective to attract target tourists (Avraham, 2015).

Service providers and managers are also greatly challenged to increase awareness to deal with the needs of multiple audiences (Timothy \& Teye, 2004; Ashworth \& Hartmann, 2005). Coles and Timothy (2004) identified three principal audiences for diasporic sites: diasporic members (migrants and their descendants), residents of original homeland (friends and relatives), and non-diaspora tourists (observers/bystanders). Mainstream tourists' attachment to the places is limited. Some tourists may be seeking a clichéd image of the place (Sizer, 1999) or simply an appealing photo opportunity, and some of their insensitive behaviours may degrade the experience for pilgrims or roots-seeking individuals (Cohen, 1999). This raises the chance of conflict between those who are visiting for a deep personal experience and those who are looking for a more superficial entertainment or leisure experience (Yankholmes \& Mckercher, 2015; Handley et al., 2006; Shackley, 2001). The chance of conflict is enhanced significantly when the tangible asset is an impressive structure, such as a fort, while the intangible heritage associated with it is far more personal (Kantanen \& Tikkanen, 2006).

Another challenge is how we can present and interpret these sites to their visitors with sensitivity and respect (Sharpley \& Stone, 2009). For example, when present some important physical reminders of the long painful history of African Slavery to their visitors, distinct aura may be arising from the associations of such sites with the diaspora's dispersion, suffering, and even death (Seaton, 2009). It indeed requires site managers to have sufficient sensitivity and carefulness when managing and maintaining this aura associated with this piece of history. A unique challenge is presented here for a unified interpretation, preservation, and management (Mowatt \& Chancellor, 2011; Seaton, 2009). Thus, some of these destinations are facing the dilemmas of managing and interpreting such heritage so as to 
satisfy competing demands for both remembering and forgetting (Tunbridge \& Ashworth, 1996).

Furthermore, the motives and intents of stakeholders, producers and consumers may also diverge. Each group has different perspectives on what is to be remembered and presented, and how it is to be interpreted in this process. For example, Ghana tourism bureau tries hard to attract their diaspora to return and invest in local tourism industry. Many African diaspora members return with great passion and desire to seek for their home, and some are encouraged to become stakeholders in the broader project of capitalist development. Nonetheless, many become aware that they are regarded as tourists and customers, and can only end with the experience of feeling as "tourists" and "outsiders" (Pinho, 2008; Handley, 2008; Nti, 2017).

\subsection{Summary of supply-side considerations}

The major concerns raised regarding supply considerations are whether and how the wide array of product available satisfies inconsistent needs of various types of tourists. The challenge can only be met through a better understanding of the segmented markets, development of correspondent marketing strategies and close and interactive cooperation among multiple stakeholders (Rimmawi \& Ibrahim, 1992; Collins-Kreiner \& Olsen, 2004). More attempts are needed to propose guidelines or frameworks for the marketing and management of these destinations. The role of management is therefore to reduce conflicts between different audiences, as well as between producers and consumers.

\section{A conceptual framework for diaspora tourism}

By critically examining current literature related to the topic, we developed a conceptual framework to understanding diaspora tourism from a more comprehensive and holistic view. The key elements identified from the demand and supply literatures suggest there are great challenges facing by current destinations in terms of understanding different diaspora groups, sub-groups and their ever-changing needs, developing differentiated market strategy, having consciousness to deal with conflicts of visitors with different quests, and fulfilling the quests of their visitors. The framework can be read from the top down, whereby an evaluation of the intricacies of the three major elements - differences in communities, level of acculturation 
and variation in sense of place - will define the motives and experiences for different tourists. It can also be read from the bottom up, by evaluating destinations' strengths, weaknesses and likely product offerings to better understand which type of diaspora tourist is likely to be attracted to which type of product.

The framework highlights the complexity of diaspora tourism, by bringing forward the heterogeneity of diaspora communities from the dimension of origin. Their migration reasons from being dispelled from their homeland to voluntarily leaving home for economic or/and lifestyle reasons; their acculturation level to the host from fully integrating to the host, adapting a multicultural tie, to maintaining a diaspora identity; and their sense of place from maintaining attached to the home place, attaching to both places, becoming attached to the host place after years of residence, to feeling placeless. These factors will influence one's perceptions of places and self: "where is home", "where I belong to", and "who am I" (Hughes \& Allen, 2010; Ioannides \& Ioannides, 2006). Thus, we argue that the demand perspective of diaspora tourism should be carefully considered with personalised features, such as migration and return reasons, quests, patterns, etc. and cannot be generalised from case studies.

The complexity also comes from the way in which destinations commodify their heritage and attractions, promote products, assess the products and services delivered to the tourists, and solve the tensions among different actors. How diasporic encounters are induced and produced, by whom and for whom, will influence participants' reasons of travel, their visit experiences, and desire to conduct repeat visit (Morgan et al., 2002; Olsen, 2006). Tourism producers and operators who have not fully realised the heterogeneity of diaspora tourists and their demands and behaviours may tend to develop generalised products and services. As a result, the repackaging and selling of existing products will weaken the appeals to diasporic tourists and more tourists may end up with unsatisfied experience. Regardless, these studies and a review of the prevailing literature suggests that the same set of supply and demand dimensions will influence tourist movement, even though the mix of and inter-relationships among each dimension will vary.

Another key to understanding this framework is to appreciate that the experiences of engaging in diaspora tourism are diversely generated from the tourists' cognitive socialpsychological parameters and inner-directed value systems (Gnoth, 1997). Their experiences range from seeking hedonic and transnational leisure experience to deep explorative and 
quest-oriented experience (Li \& McKercher, 2016a; Alexander, Bryce, \& Murdy, 2017; Huang, Norman, \& Ramshaw, 2015). The types of experiences they can achieve will be associated with their purposes, migration background, personal histories, connections, and etc., and can be facilitated by the performance of the destination and local communities. For instance, reactive migrants may feel rootless and not assimilate well into the host community. Instead, they may prefer to isolate themselves within ethnic enclaves and feel more attached to a place they cannot visit in the short term. When they can travel, it is likely that their experiences will be akin to a quest (Basu, 2007; Pinho, 2008), which may in turn mean they are open to visiting dark tourism sites and sacred places (Hollinshead, 2004; Wilson \& Dissanayake, 1996; Duval, 2004). They may also feel a greater sense of entitlement to visit some places, potentially creating conflict between them and other leisure-oriented tourists. Those who have fully integrated into the host community have been resident for many generations and who feel at home there, may travel widely throughout the place of origin more for general touristic reasons, visiting iconic cities and sights or to become re-connected with their heritage (Basu, 2007; Franklin \& Crang, 2001; McCain \& Ray, 2003). Others may feel strong attachment to their ethnic culture and may seek experiences that re-affirm that connection (Stefansson, 2004). Conversely, those migrants who migrated recently have strong ties to ancestral home and tend to restrict their movements to the vicinity of their ancestral homes where they still have affective and cognitive connection (Li \& McKercher, 2016b). Those individuals who developed strong and specific attachment to current place of residence adopted a more dispersed movement pattern involving visits to their ancestral region. For others still, the trip may have little more meaning than a holiday with a sense of cultural exoticism (King, 1994).

Overall, demand-side factors such as the tourists' migration background, identity and sense of place, as well as supply-side elements such as what kinds of products and services the destinations provide, how well the site managers deal with different types of tourists, and how interactive and cooperative different actors play, will together lead to tourists' motives and experiences of visit.

\section{Conclusion remarks}


This study reviews a wide range of studies in tourism, migration, and destination management, and organises the literature into an integrative framework that constitutes a synthesis of the constructs in both demand and supply perspectives.

\subsection{Research implications}

By involving interdisciplinary discussions on the researched topic, this paper provides a number of implications for researchers and practitioners. First, it offers a more comprehensive and holistic view to understand diaspora tourism by integrating key themes and issues of both origin and destination aspects. This does not mean we have moved beyond the "context-specific" stance to make generalisation from diversified diaspora groups; instead we aim to acknowledge the diversification of different diasporas, their varied migration history, personal history, sense of place and identity, and to unveil the complexity of diaspora tourism and the mechanism that may play a role in driving their travel. Second, through the conceptual framework, concerns are raised about how destination managers can apply what we have learnt from the most up-to-date research to destination marketing and product development. We argue that a better understanding of the heterogeneity of diaspora (sub)communities will be beneficial for DMOs in terms of uncovering different quests that diaspora groups may have, and consequently tackling the question of how to satisfy their needs. Further, the refinement and application of this framework will clarify the understanding of relationships between diaspora tourism and related concepts, such as roots tourism, heritage tourism, pilgrimage, dark site tourism, VFR, and so forth, and offer a coherent structural alternative to these related concepts that previously remained scattered in the literature. The framework will serve as a start point for further theoretical explorations and practical domains in future research.

\subsection{Future research agenda}

The proposed framework gives rise to a number of promising research avenues that deserves further attention in migration, diaspora and tourism studies. A research agenda is presented around three key themes with the endeavours of progressing on more devoted future research.

First, exploring other types of diaspora travel. Current literature has been dominated by home return travel or "homecoming" of the diaspora communities, and overlooked other significant types such as the travel of residents in the original homeland to diasporic spaces, and the 
travel of diasporic members to the spaces of transit or dispersion (Coles \& Timothy, 2004; Cater, Poguntke, \& Morris, 2019). These types of diaspora travel are increasingly important for their significance in linking different groups, places, and identities. Future research should go beyond home return visit and take the other types of diaspora travel into account for developing a more comprehensive understanding of this globally significant phenomenon.

Second, bridging destinations to their diasporas. Another future research priority could include more supply-side investigations on how DMOs develop further understanding about their different types of audiences and innovative marketing strategies through communicating with researchers, consultants, voluntary associations, etc. (Kelner, 2010; Hughes \& Allen, 2010). Here, issues of how communication, social media and research outputs help to bridge the gap between the tourists and the destinations are worth of more detailed discussions. The proposed framework could also be used to evaluate existing or potential conflicts that may occur at the destination. More advanced strategies are anticipated to be developed for managing these conflicts, which will consequently lead to a more authentic and harmonious experience for diaspora tourists.

Third, the dynamic process of producing diaspora tourism experiences. Rather than a category of motivations and market segmentations, diaspora tourism offers multifaceted, introspective, sensory, transformative and spiritual experiences for migrants through creating "moments of home", enhancing cultural connectedness and self-acceptance, and reinforcing their collective and self-identity (Etemaddar et al., 2016; Alexander et al., 2017; Light, 2017; Trauer \& Ryan, 2005; Li \& Chan, 2017). Nonetheless, the process through which diaspora travel produces such experience should be considered as multifaceted and dynamic and will need more in-depth explorations. The relationships between diaspora travel experiences and sense of well-being could be another topic that deserves further concerns.

Fourth, sociological perspectives of diasporic return. Future research could also extend discussions on migrants' social engagements, in terms of how different social contexts and diaspora's interactions with their significant others help to shape the tourists' experiences; how home return travel experience influences local and transnational social networks and social capital building (Li, 2019; Lew \& Wong, 2004; Zhou \& Lee, 2015). This avenue offers a promising path forward by engaging more sociological debates over the complex relationships between diasporas, transnationalism, and social networks. 


\section{References:}

Alba, R., \& Nee, V. (1997). Rethinking assimilation theory for a new era of immigration. International migration review, 826-874.

Alexander, M., Bryce, D., \& Murdy, S. (2017). Delivering the past: providing personalized Ancestral Tourism experiences. Journal of Travel Research, 56(4), 543-555.

Ali, N., \& Holden, A. (2006). Post - colonial Pakistani mobilities: the embodiment of the 'myth of return'in tourism. Mobilities, 1(2), 217-242.

Ang, I. (2014). Beyond Chinese groupism: Chinese Australians between assimilation, multiculturalism and diaspora. Ethnic and Racial Studies, 37(7), 1184-1196.

Ashworth, G., \& Hartmann, R. (2005). Horror and human tragedy revisited: the management of sites of atrocities for tourism. Cognizant Communication Corporation.

Avraham, E. (2015). Destination image repair during crisis: Attracting tourism during the Arab Spring uprisings. Tourism Management, 47, 224-232.

Bahamas Ministry of Tourism. (2017). Homecoming. Retrieved 11 April, 2017, from http://www.tourismtoday.com/events/homecoming

Basu, P. (2004). Route metaphors of 'roots-tourism' in the Scottish Highland diaspora. In S. Coleman \& J. Eade (Eds.), Reframing pilgrimage: cultures in motion. London: Routledge.

Basu, P. (2005). Roots tourism as return movement: semantics and the Scottish diaspora. In M. Harper (Ed.), Emigrant homecomings: The return movement of emigrants, 16002000 (pp. 131-150). Manchester: Manchester University Press.

Basu, P. (2007). Highland Homecomings: Genealogy And Heritage Tourism in the Scottish Diaspora. New York: Routledge.

BBC. (2012). Sierra Leone seeks to move into 'slave tourism'. Retrieved 11 April, 2017, from http://www.bbc.co.uk/news/world-africa-18613200. 
Benet - Martínez, V., \& Haritatos, J. (2005). Bicultural identity integration (BII): Components and psychosocial antecedents. Journal of personality, 73(4), 1015-1050.

Benson, M., \& O'Reilly, K. (2009). Migration and the search for a better way of life: a critical exploration of lifestyle migration. The sociological review, 57(4), 608-625.

Berg, M. L. (2011). Diasporic generations: Memory, politics, and nation among Cubans in Spain (Vol. 33). USA: Berghahn Books.

Berry, J. W. (1997). Immigration, acculturation, and adaptation. Applied psychology, 46(1), 5-34.

Bhabha, H. K. (1994). The location of culture. New York: Routledge.

Boyne, S., Carswell, F., \& Hall, D. (2002). Reconceptualizing VFR Tourism: friends, relatives and migration within a domestic context. In C. M. Hall \& A. M. Williams (Eds.), Tourism and Migration: New Relationships between Production and Consumption (pp. 240-256). Morwell: Kluwer Academic.

Brubaker, R. (2005). The 'diaspora'diaspora. Ethnic and Racial Studies, 28(1), 1-19.

Bruner, E. (1996). Tourism in Ghana: The Representation of Slavery and the Return of the Black Diaspora American Anthropologist, 98(2), 290-304.

Bryce, D., Murdy, S., \& Alexander, M. (2017). Diaspora, authenticity and the imagined past. Annals of Tourism Research, 66, 49-60.

Butler, D. L. (2001). Whitewashing plantations: The commodification of a slave-free Antebellum South. International journal of hospitality \& tourism administration, 2(3-4), 163-175.

Cater, C., Poguntke, K., \& Morris, W. (2018). Y Wladfa Gymreig: Diasporic tourism and the role of identity. Tourism Geographies. DOI: 10.1080/14616688.2019.1571095

Castles, S. (2000). International Migration at the Beginining of the Twenty - First Century: Global Trends and Issues. International Social Science Journal, 52(165), 269-281.

Che, D. (2004). Reinventing Tulip Time. In T. Coles \& D. J. Timothy (Eds.), Tourism, diasporas, and space (pp. 261-278). New York: Routledge.

Cohen, R. (1997). Global Diasporas: An Introduction. London: Routledge.

Cohen, E. H. (1999). Informal marketing of Israel Experience educational tours. Journal of travel Research, 37(3), 238-243.

Cohen, E. H. (2011). Educational dark tourism at an in populo site: The Holocaust Museum in Jerusalem. Annals of Tourism Research, 38(1), 193-209.

Coles, T. (2004). Diaspora, cultural capital and the production of tourism. In T. Coles \& D. J. Timothy (Eds.), Tourism, diasporas, and space (pp. 217-232). New York: Routledge.

Coles, T., \& Timothy, D. J. (2004). Tourism, Diasporas and Space. New York: Routledge.

Collins-Kreiner, N. (2010). Researching pilgrimage: Continuity and transformations. Annals of Tourism Research, 37(2), 440-456.

Collins-Kreiner, N., \& Olsen, D. (2004). Selling diaspora. In T. Coles \& D. J. Timothy (Eds.), Tourism, diasporas, and space (pp. 279-290). New York: Routledge.

Cuba, L., \& Hummon, D. M. (1993). A place to call home: Identification with dwelling, community, and region. The sociological quarterly, 34(1), 111-131.

Dann, G. M., \& Seaton, A. V. (2001). Slavery, contested heritage and thanatourism. International journal of hospitality \& tourism administration, 2(3-4), 1-29.

Davidson, A. P. (2008). The play of Identity, Memory and Belonging: Chinese Migrants in Sydney. In K. E. Kuah-Pearce \& A. P. Davidson (Eds.), At Home In The Chinese Diaspora: Memories, Identities and Belongings. London: Palgrave Macmillan.

Drozdzewski, D. (2007). A place called 'Bielany': Negotiating a diasporic Polish place in Sydney. Social \& Cultural Geography, 8(6), 853-869. 
Duval, D. T. (2004). Linking return visits and return migration among Commonwealth Eastern Caribbean migrants in Toronto. Global Networks, 4(1), 17.

Eckstein, S. (2002). On deconstructing and reconstructing the meaning of immigrant generations. In P. Levitt \& M. C. Waters (Eds.), The changing face of home: The transnational lives of the second generation (pp. 211-215).

Elliot, S., Papadopoulos, N., \& Kim, S. S. (2011). An integrative model of place image: Exploring relationships between destination, product, and country images. Journal of Travel Research, 50(5), 520-534.

Eng, K., \& Davidson, A. (2007). At home in the Chinese diaspora: Memories, identities and belongings: New York, NY: Palgrave Macmillan.

Feng, K., \& Page, S. J. (2000). An exploratory study of the tourism, migration-immigration nexus: Travel experiences of Chinese residents in New Zealand. Current Issues in tourism, 3(3), 246-281.

Franklin, A., \& Crang, M. (2001). The trouble with tourism and travel theory? Tourist Studies, $1(1), 5-22$.

Fried, M. (1963). Grieving for a lost home. In L. J. Duhl (Ed.), The urban condition (pp. 151171). New York: Basic Books.

Fussell, E. (2012). Space, time, and volition: Dimensions of migration theory. In M. R. Rosenblum \& D. J. Tichenor (Eds.), The Oxford Handbook of the Politics of International Migration (pp. 25-52). New York: Oxford University Press Oxford.

Gnoth, J. (1997). Tourism motivation and expectation formation. Annals of Tourism Research, 24(2), 283-304.

Gordon, M. M. (1964). Assimilation in American life: The role of race, religion and national origins. New York: Oxford University Press.

Grant, M. J., \& Booth, A. (2009). A typology of reviews: an analysis of 14 review types and associated methodologies. Health Information \& Libraries Journal, 26(2), 91-108.

Gustafson, P. (2001). Retirement migration and transnational lifestyles. Ageing and Society, 21,371 .

Handley, F. J., Haviser, J., \& MacDonald, K. (2006). Back to Africa. Issues of hosting 'Roots' tourism in West Africa. African re-genesis. Confronting social issues in the diaspora, London, 20-31.

Hannam, K. (2004). India and the ambivalences of diaspora tourism. In T. Coles \& D. J. Timothy (Eds.), Tourism, diasporas, and space (pp. 246-260). New York: Routledge.

Harker, K. (2001). Immigrant generation, assimilation, and adolescent psychological wellbeing. Social forces, 79(3), 969-1004.

Harvey, D. (1993). From space to place and back again: Reflections on the condition of postmodernity. In J. Bird, B. Curtis, T. Putnam, G. Robertson \& L. Tickner (Eds.), Mapping the futures: local cultures, global change. New York: Routledge.

Hay, R. (1998). Sense of place in developmental context. Journal of environmental psychology, 18, 5-29.

Hollinshead, K. (2004). Tourism and third space populations. The restless motion of diaspora peoples. In T. Coles \& D. J. Timothy (Eds.), Tourism, Diasporas and Space. London: Routledge.

Hughes, H., \& Allen, D. (2010). Holidays of the Irish diaspora: the pull of the 'homeland'? Current Issues in Tourism, 13(1), 1-19.

Huang, W. J., Norman, W. C., Ramshaw, G. P., \& Haller, W. J. (2015). Transnational leisure experience of second-generation immigrants: The case of Chinese-Americans. Journal of Leisure Research, 47(1), 102-124. 
Iarmolenko, S. (2015). Bridging tourism and migration mobilities: Diaspora tourism as a coping strategy. European Journal of Tourism Research, 11, 171.

Ioannides, M. W. C., \& Ioannides, D. (2006). Global Jewish Tourism. In D. Timothy \& D. Olsen (Eds.), Tourism, religion and spiritual journeys (pp. 156). Oxford, UK: Routledge.

Kantanen, T., \& Tikkanen, I. (2006). Advertising in low and high involvement cultural tourism attractions: Four cases. Tourism and Hospitality Research, 6(2), 99-110.

Kelner, S. (2010). Tours that bind: diaspora, pilgrimage, and Israeli birthright tourism. New York: NYU Press.

Kelner, S., Saxe, L., Kadushin, C., Canar, R., Lindholm, M., Ossman, H., . . . Wolf, M. (2000). Making meaning: participants' experience of Birthright Israel (Vol. Brithright Israel Research Report 2): Cohen Center for Modern Jewish Studies, Brandeis University.

Kemp, C., \& Chang, B. J. (2004). China. In C. Kemp, \& L. A. Rasbridge (Eds.), Refugee and immigrant health: A handbook for health professionals (pp. 132-141). Cambridge: Cambridge University Press.

Kim, H.-R., \& Oh, I. (2011). Migration and multicultural contention in East Asia. Journal of Ethnic and Migration Studies, 37(10), 1563-1581.

King, B. (1994). What is ethnic tourism? An Australian perspective. Tourism Management, 15(3), 173-176.

King, R., \& Christou, A. (2010). Cultural geographies of counter - diasporic migration: perspectives from the study of second - generation 'returnees' to Greece. Population, Space and Place, 16(2), 103-119.

Klemm, M. S. (2002). Tourism and ethnic minorities in Bradford: The invisible segment. Journal of travel Research, 41(1), 85-91.

LaFromboise, T., Coleman, H. L., \& Gerton, J. (1993). Psychological impact of biculturalism: Evidence and theory. Psychological bulletin, 114(3), 395.

Lee, E. (2003). At America's gates: Chinese immigration during the exclusion era, 18821943. Chapel Hill: University of North Carolina Press.

Lew, A., \& Wong, A. (2004). Sojourners, guanxi and clan associations: social capital and overseas Chinese tourism in China. In T. Coles \& D. J. Timothy (Eds.), Tourism, diasporas and space. New York: Routledge.

Lewicka, M. (2011). Place attachment: How far have we come in the last 40 years? Journal of environmental psychology, 31(3), 207-230.

Li, T. E., \& McKercher, B. (2016a). Developing a typology of diaspora tourists: Return travel by Chinese immigrants in North America. Tourism Management, 56, 106-113.

Li, T. E., \& McKercher, B. (2016b). Effects of place attachment on home return travel: a spatial perspective. Tourism Geographies, 18(4), 359-376.

Li, T. E., \& Chan, E. T. H. (2017). Diaspora tourism and well-being: A eudaimonic view. Annals of Tourism Research, 63, 205-206.

Li, T. E., \& Chan, E. T. H. (2018). Connotations of ancestral home: An exploration of place attachment by multiple generations of Chinese diaspora. Population, Space and Place, 24(8), e2147.

Li, T. E. (2019). Guanxi or weak ties? Exploring Chinese diaspora tourists' engagements in social capital building. Current Issues in Tourism, 1-16.

Light, D. (2017). Progress in dark tourism and thanatourism research: An uneasy relationship with heritage tourism. Tourism Management, 61, 275-301.

Low, S. M., \& Altman, I. (1992). Place attachment: A conceptual inquiry Place attachment (pp. 1-12): Springer. 
Maddern, J. (2004). The Isle of Home is always on your mind: subjectivity and space at Ellis Island Immigration Museum. In T. Coles \& D. Timothy (Eds.), Tourism, diasporas and space: travels to promised lands. London Routledge.

Maliepaard, M., Lubbers, M., \& Gijsberts, M. (2010). Generational differences in ethnic and religious attachment and their interrelation. A study among Muslim minorities in the Netherlands. Ethnic and Racial Studies, 33(3), 451-472.

Maruyama, N., \& Stronza, A. (2011). Roots tourism of Chinese Americans. Ethnology: An International Journal of Cultural and Social Anthropology, 49(1), 23-44.

Mazumdar, S., \& Mazumdar, S. (2009). Religion, immigration, and home making in diaspora: Hindu space in Southern California. Journal of environmental psychology, 29(2), 256-266.

McCain, G., \& Ray, N. M. (2003). Legacy tourism: The search for personal meaning in heritage travel. Tourism Management, 24(6), 713-717.

McHugh, K. E., \& Mings, R. C. (1996). The circle of migration: Attachment to place and aging. Annuals of the Association of American Geographers, 86, 530-550.

Modood, T. (2013). Multiculturalism (Vol. 2).: John Wiley \& Sons.

Moore-Gilbert, B. (1997). Postcolonial Theory: Contexts, Practices, Politics. London: Verso Books.

Morgan, N., Pritchard, A., \& Pride, R. (2002). Marketing to the Welsh diaspora: The appeal to hiraeth and homecoming. Journal of Vacation Marketing, 9(1), 69-80.

Mowatt, R. A., \& Chancellor, C. H. (2011). Visiting death and life: Dark tourism and slave castles. Annals of Tourism Research, 38(4), 1410-1434.

Murdy, S., Alexander, M., \& Bryce, D. (2018). What pulls ancestral tourists 'home'? An analysis of ancestral tourist motivations. Tourism Management, 64, 13-19.

Newland, K., \& Taylor, C. (2010). Heritage tourism and nostalgia trade: a diaspora niche in the development landscape. Washington, DC: Migration Policy Institute.

Nurse, K. (2002). Bringing culture into tourism: festival tourism and Reggae Sunsplash in Jamaica. Social and Economic Studies, 127-143.

Olsen, D. H. (2006). Management issues for religious heritage attractions. In D. J. Timothy \& H. O. Daniel (Eds.), Tourism, religion and spiritual journeys (pp. 104-118). New York: Routledge.

Pan, L. (1998). The Encyclopedia of the Chinese Overseas Chinese. Singapore: Chinese Heritage Centre.

Phinney, J. S., Horenczyk, G., Liebkind, K., \& Vedder, P. (2001). Ethnic identity, immigration, and well-being: An interactional perspective. Journal of social issues, 57(3), 493-510.

Philippine Department of Tourism. (2017). Pinoy Homecoming. Retrieved 14 April, 2017, from http://www.pinoyhomecoming.com.ph/about.do

Pinho, P. (2008). African-American roots tourism in Brazil. Latin American Perspectives, 35, $70-86$.

Reed-Danahay, D. (2015). 'Like a foreigner in my own homeland': writing the dilemmas of return in the Vietnamese American diaspora. Identities, 22(5), 603-618.

Relph, E. (1976). Place and placelessness. London: Pion Limited.

Richmond, A. H. (2002). Globalization: Implications for immigrants and refugees. Ethnic and Racial Studies, 25(5), 707-727.

Rimmawi, H. S., \& Ibrahim, A. A. (1992). Culture and tourism in Saudi Arabia. Journal of Cultural Geography, 12(2), 93-98. 
Rumbaut, R. G. (2004). Ages, life stages, and generational cohorts: Decomposing the immigrant first and second generations in the United States. International migration review, 38(3), 1160-1205.

Safran, W. (1991). Diasporas in modern societies: Myths of homeland and return. Diaspora: A Journal of Transnational Studies, 1(1), 83-99.

Sam, D. L., \& Berry, J. W. (2010). Acculturation: When individuals and groups of different cultural backgrounds meet. Perspectives on psychological science, 5(4), 472-481.

Sampson, R., \& Gifford, S. M. (2010). Place-making, settlement and well-being: The therapeutic landscapes of recently arrived youth with refugee backgrounds. Health \& place, 16(1), 116-131.

Schoene-Harwood, B. (1998). 'Emerging As the Others of Our Selves'-Scottish Multiculturalism and the Challenge of the Body in Postcolonial Representation. Scottish Studies Review, 25(1), 54.

Schwartz, S. J., Unger, J. B., Zamboanga, B. L., \& Szapocznik, J. (2010). Rethinking the concept of acculturation: implications for theory and research. American Psychologist, 65(4), 237.

Seaton, T. (2009). Purposeful otherness: Approaches to the management of thanatourism.In R. Sharpley, \& P. R. Stone (Eds.), The darker side of travel: The theory and practice of dark tourism (pp.75-108). Bristol: Channel View.

Shackley, M. (2001). Managing sacred sites: Service provision and visitor experience. UK: Continuum.

Sharpley, R., \& Stone, P. R. (Eds.). (2009). The darker side of travel: The theory and practice of dark tourism. Channel view publications.

Shani, A., \& Wang, Y. (2011). Destination image development and communication. In Y. Wang \& A. Pizam (Eds.), Destination Marketing and Management: Theories and Applications. Oxford: CAB International.

Shapiro, F. L. (2001). Learning to be a diaspora Jew through the Israel experience. Studies in Religion, 30(1), 23-34.

Sizer, S. R. (1999). The ethical challenges of managing pilgrimages to the holy land. International Journal of Contemporary Hospitality Management, 11(2), 85-90.

Stedman, R. C. (2006). Understanding place attachment among second home owners. American behavioral scientist, 50(2), 187-205.

Stefansson, A. H. (2004). Homecomings to the future: from diasporic mythographies to social projects of return. Homecomings: Unsettling paths of return, 2-20.

Stephenson, M. L. (2002). Traveling to the Ancestral Homelands: the Aspirations and Experiences of a UK Caribbean Community. Current issues in tourism, 5(5).

Stone, P. (2006). A dark tourism spectrum: Towards a typology of death and macabre related tourist sites, attractions and exhibitions. Tourism: An Interdisciplinary International Journal, 54(2), 145-160.

Stone, P., \& Sharpley, R. (2008). Consuming dark tourism: A thanatological perspective. Annals of Tourism Research, 35(2), 574-595.

Timothy, D. J. \& Teye, V. B. (2004). American children of the African diaspora: Journeys to the motherland. In T. Coles \& D. Timothy (Eds.), Tourism, diasporas and space (pp. 111-123). Routledge.

Tie, C., Holden, A., \& Park, H.Y. (2015). A 'reality of return': The case of the SarawakianChinese visiting China. Tourism Management, 47, 206-212.

Timothy, D., \& Olsen, D. (2006). Tourism, religion and spiritual journeys (Vol. 4). New York: Routledge. 
Trauer, B., \& Ryan, C. (2005). Destination image, romance and place experience-an application of intimacy theory in tourism. Tourism Management, 26(4), 481-491.

Tsai, J. L., Ying, Y.-W., \& Lee, P. A. (2000). The meaning of "being Chinese" and "being American" variation among Chinese American young adults. Journal of CrossCultural Psychology, 31(3), 302-332.

Tunbridge, J. E., \& Ashworth, G. J. (1996). Dissonant heritage: The management of the past as a resource in conflict. John Wiley \& Sons.

United Nations. (2016). International Migration Report 2015: Highlights. Department of Economic and Social Affairs Population Division (pp. 36).

Van den Berghe, P. L. (1994). The quest for the other: Ethnic tourism in San Cristóbal, Mexico. Seattle: University of Washington Press.

Vertovec, S. (2001). Transnationalism and identity. Journal of Ethnic and Migration Studies, 27(4), 573-582.

Vertovec, S. (2004). Religion and diaspora. In P. Antes, A. W. Geertz \& R. R. Warne (Eds.), New approaches to the study of religion (Vol. 2, pp. 275-304).

VisitScotland. (2009). Homecoming Scotland 2009 - The story. Retrieved 11 April, 2017, from http://www.visitscotland.org/pdf/homecoming_scotland_2009_-_the_story.pdf

Weaver, D. B., Kwek, A., \& Wang, Y. (2017). Cultural connectedness and visitor segmentation in diaspora Chinese tourism. Tourism Management, 63, 302-314.

Weick, K. E. (1999). Theory construction as disciplined reflexivity: Tradeoffs in the 90s. Academy of Management Review, 24(4), 797-806.

Wessendorf, S. (2007). 'Roots migrants': transnationalism and 'return'among secondgeneration Italians in Switzerland. Journal of Ethnic and Migration Studies, 33(7), 1083-1102.

Wilson, R., \& Dissanayake, W. (1996). Introduction: tracking the global/local. In R. Wilson \& W. Dissanayake (Eds.), Global/Local: Cultural Production and the Transnational Imaginary (pp. 1-18). Durham: Duke University Press.

Yankholmes, A., \& McKercher, B. (2015). Understanding visitors to slavery heritage sites in Ghana. Tourism Management, 51, 22-32.

Žabčić, M. R. (2010). Festivals in Diaspora as connection with Croatian migrant communities with their homeland: example film festival in Melbourne, Australia. Paper presented at the Journey of Expression VIII: Celebrating throught Times of Crisis: Prospects and Potential for Tourism, Festivals and Cultural Events, Kopenhagen, Danska.

Zhou, M. (2015). Changing Generational Dynamics in Chinese America across Time. Diaspora: A Journal of Transnational Studies, 18(1), 89-116.

Zhou, M., \& Lee, R. (2013). Transnationalism and community building: Chinese immigrant organisations in the United States. The annals of the American academy of political and social science, 647(1), 22-49.

Zhou, M., \& Lee, R. (2015). Traversing ancestral and new homelands: Chinese immigrant transnational organisations in the United States. The State and the Grassroots: Immigrant Transnational Organisations in Four Continents, 27-50. 